\title{
The Problems in will Expression in Civil Law Transactions and Healthcare in Case of Capacity of Individuals
}

\author{
Inga Kudeikina ${ }^{1}$ and Karina Palkova ${ }^{2}$
}

\begin{abstract}
The expression of each individual's will is one of the important rights. This freedom is protected by human rights. In legal systems the expression of the central positions of the will of individuals is protected. In civil law transactions as well as in health care individuals have specific and complicated rights to express their will. And the problematics of it comes from that capacity issue. The rights to expression, rights to liberty ect. are recognized as the basic rights of each individual, of each member of the society. The protection of the expression of the individual's will is significant moment from the international as well as national point of view. A significant aspect and more sensitive is the protection of incapable person's rights, for instance, in civil law transactions and healthcare matters in legal framework. The key challenge for the protection of those rights is to find the balance between capable and incapable persons' rights protection in the case of will expression in particular matters.
\end{abstract}

Keywords: legal capacity, decision, treatment, willpower, civil law

\section{Introduction}

No person's life can be imagined without conclusion of civil law transactions. Such are also receiving of medical services. It would not be reasonable to think that medical treatment is excluded from civil law transactions. The authors emphasize that medical treatment is a complex civil law transaction, subject to both general provisions applicable to legal transactions and special provisions, which regulate the legal relations of the medical practitioner and the patient in the treatment process.

The transactions are concluded both verbally, by default actions and in writing. Will of the party of the transaction is an important component of the transactions regardless of the form of conclusion. Problem issues are encountered in situations when doubts emerge regarding the will of the party of the transactions, namely, the mental health of the individual may prevent it from being aware of its actions and control it. In the law such condition of the person is denominated as incapacity.

Legal framework separates cases then when the capacity of the person is limited due to the age (persons lack capacity until becoming of age) or on the grounds of the court judgement, from cases, when the person becomes incapacitated in regard to the specific transaction as a result of a previously undefined legal fact. Transactions concluded by such persons shall be declared as null and void. Minor persons are represented by 
guardians, the persons, whose capacity has been limited by the court, are represented by the trustees, who are entitled to express the will of the persons they represent, while the persons, whose capacity has not been limited at all, but who have been incapacitated only at the moment of conclusion of the transactions, since the faults of their will were caused by alcohol intoxication, drug intoxication or other substances, are not represented by anyone. The control of expression of the will lies only with other party of the transaction or the official, if such has been involved in the transaction (for example, sworn notary, medical practitioner, employee of the registry office, etc.).

The article analyses only the will of an individual and the problem issues of expression thereof, considering that the individual person possesses capacity and accordingly faults of the capacity, which affect the will of the person, are possible.

\section{Research.}

\subsection{Problem issues of will in civil law transactions in the case of incapacity}

A legal transaction is a free and voluntary agreement of the contracting parties for the purpose of establishing, amending or terminating of legal relations. Transaction as a legal relationship, involves both a commitment by the parties to acquire material assets and a legal relationship the value of which is not quantifiable. If in the first case these are different types of contract, then in the second it is medical treatment. In the treatment process, the legal subject is endowed with special rights - the patient's rights, but it must be emphasized that, despite the existence of a special right, primarily civil law relationships are nevertheless established between the medical practitioner and the patient. There is also a voluntary principle in medical treatment that requires the individual to give informed consent to the treatment. Only in certain limited cases, treatment is permitted without the patient's consent. This legal framework is provided by the 2009 Law On the Rights of Patients. Thus, the will of the person is also essential in treatment.

Civil law relationships are based on the parties' self-determination rights and dispositivity. Given that this is a relationship of persons with equal rights, it is essential that each party is legally and effectively capable of exercising its subjective rights to the full extent. This is the only way to ensure a balanced legal relationship in which the parties knowingly commit and honour their obligations. Such an approach is inherent in a modern and democratic state and helps to ensure peaceful coexistence of members of society, which ensures sustainable development. These principles are not new, they stem from the declared principles of the School of Natural Law, mentioned in her article by a Latvian scientist, currently a judge of the Constitutional Court of the Republic of Latvia, S. Osipova (Osipova: 2006). In addition, it should be emphasized that they are embedded in a number of international and national legislative enactments. The main legal act is a generally well know legal act - the UN Universal Declaration of Human Rights, which states, inter alia, that the full respect for the dignity of all members of human society and the recognition of their equal and inalienable rights, is the foundation of freedom, justice and peace in the world. Special rules are derived from this principle. Will is the central element of any civil law transaction. Will can be described as the determined and motivated desire of the subject of law to achieve the set goal (Kudeikina: 2015), while lack of will creates the basis for invalidation of the transaction. Interpreting 
the linguistic meaning of the term "will" leads to the conclusion that will is a set of mental events that is manifested in purposeful and conscious action (Latvian Oxford Livings Dictonaries). The definition leads to the conclusion that the will can be seen not only in the aspect of law but also in other branches of science - psychology, medicine. There are qualifying features that separate the perception of will in law from perception the concept of will in other disciplines. In law, it is intended to mean a person's intentional act or omission, the ability to purposefully act or to refrain from acting, the ability to understand the causal link between one's own act or omission, the ability to understand the legal consequences of an act or omission. It is essential in law science that the totality of the above features has been created and executed freely, that is, without false, delusional or coercive means.

Section 140 of the Civil Law stipulates that for a lawful transaction to be in force it shall not suffice for the participants to express their intent, but it is also necessary for the intent to originate from their own free will, without mistake, fraud or duress. (Civil Law. Obligations Law: 1937). The scope of each legal transaction must analyse the will of the party and the circumstances, in which it is expressed. Given that will is a set of mental events, it must be concluded that it is possible to establish the will by establishing the person's mental health. However, the assessment of mental health would be incomplete, since, as mentioned above, in law, the understanding of will is broader than just a set of mental events, then not only the medical aspect (set of mental events) but also the legal the person's ability to be aware of its conduct and its legal consequences, shall be considered in assessment of the will. Mental illness does not in itself cause defects in the will. A person may suffer from a mental illness and at the same time be fully aware of and control his or her activities, but it may be otherwise - that a person who is mentally healthy, due to special circumstances, is unable to recognize and control his or her actions. Therefore, in law we can speak of an institute that is broader than will - capacity. A person's capacity to act is assessed at a specific time in relation to a particular transaction by determining whether the person was capable at the time of the particular transaction. Unlike legal capacity, the criterion of capacity to act is not directly linked to birth. Signs of the capacity to act as law institute are specified in Sections 1407 and 1408 of the Civil Law (Civil Law. Obligations Law: 1937), from which it is concluded that all persons of age, for whom no custody has been established due to mental illnesses or other health disorders, shall be deemed as capable to act. It is evident that these signs are associated with a previously known and static condition. These signs of incapacity can be easily established in an uncontested procedure in the organization of the transaction and it may be accepted that there is no dispute in the case law regarding the interpretation of this regulation. It is different with the establishment of a person's incapacity in a particular transaction if the reason for the incapacity is a person's state of unconsciousness or any condition that prevents the person from understanding or directing the meaning of his or her actions. Expresis verbis does not specify any criteria, which would allow identifying criteria, which in such cases would allow establishing incapacity of the person. In practice, such are alcohol or drug intoxication, severe mental or emotional agitation. Thus, in summing up, one must agree with the legal doctrine that capacity to act is a general characteristic of a person's status, which is based on the assumption that adults without mental illness are able to adequately express their will in 
transactions. However, capable persons may have short-term disorders of consciousness and will, which cannot be ignored (Torgans: 2000).

Capacity to act is the basis for declaring the transaction as null and void. Section 1405 of the Civil Law together with Section 1409 allows concluding that transactions, made by incapable persons, are null and void. (Civil Law. Obligations Law: 1937). The case law analysis indicates the necessity of evaluating a particular transaction, ascertaining whether, at the time of the conclusion of the transaction, the person had such temporary disruptions of consciousness and will, which cannot be ignored. Therefore, it is important to find out the causes of unconsciousness or mental disorder that may be the basis for the invalidity of the transaction (Department of Civil Cases of the Supreme Court of the Republic of Latvia: 2017).

The consequence of incapacity is a lack of will on the part of the person. A person may actually perform actions or, on the contrary, refrain from acting, but the person's actions are not intentional, the person does not understand the circumstances and legal consequences of his or her actions. Of course, such a transaction can be considered to be unintentionally concluded. If one of the parties entered into the transaction 'unknowingly', the parties were not in the same position. A party who has entered into a transaction in a state of incapacity shall be considered as the weaker party, who, due to his or her situation, has been unable to fully and properly exercise his or her rights. In civil law relations, such a situation is not permissible. As emphasized above, the essence of civil relations is equality between the parties, which allows each of the parties to be an equal counterparty of the transactions. Otherwise there would be a situation in which one of the parties could illegally exploit the other party's inability (lack of will) to its advantage. It is obvious that this would border on fraud and create instability in civil relations. Referring to case law, the author has previously stated that the will of a person in private law relations is a subjective and at the same time obligatory element for concluding a transaction (Kudeikina: 2015).

\subsection{Characterization of the problem of expression of will of an incapacitated patient.}

The institute of the expression of the persons' will can be found also in healthcare cases.

The will of the person in healthcare cases means the rights of this person not only to make decision in particular healthcare cases, but also truly consent to treatment, give permission before, during and after the treatment and it is an important part of the medical law, the patients' rights and of the Human Rights law. In our days the autonomy of the individuals, hence, patients ought to be valued (Zapotoczna Z.:2019). Therefore, the requirements for the expression of the patients' will must be valid, understandable and respectable from the perspective of the human rights.

The central position of an individual and the protection of their individual rights of willpower in healthcare is mostly defined at national and international level. It can be national legal acts, specific treaties, directives or regulations, European Charter of Patients' Rights or the documents of the World Health Organizations.

For instance, in Latvia, the national basic legal act that includes the material legal norms is the Law On the Rights of Patients (Law On the Rights of Patients: 2009). The Article 
3 of Paragraph 6 of the Law states that healthcare against the will of a patient shall not be permissible, if not otherwise laid down by the Law. The prohibition of the ignorance of the patient's will is based not only on patient's nondiscrimination principle, but as well as on human rights principles as whole. It shall be noted, that plenty of legal instruments lay down the conditions under which the will of the person as individual can to co -exist with the equal wills of all other individuals, who at the same time are subjects of a general law of freedom (Herbert, 1996)

Besides, the expression of an individuals' will in a legal transaction can be characterized by the fact that it is a double institute that consists of several elements: external expression of an individuals' will and expression of inner will of an individual (Torgans K.: 2018). Therefore, one of the questions is what kind of will does an individual as a patient use in the cases of decision-making process. The relationship of the patient and the medical practitioner in healthcare are based on patient's wishes and some criteria that show the real will of the patient. But most important thing is to identify the origin of the patient's will. (Mazure L.: 2011.)

In that case the will of the patient can be initial or derivative. Initial person's will can be explained as the patient's will, which expressed for the first time for the particular kind of treatment. But derivative person's will can be explained as the patient's decision that cancels the previous wish. Therefore, it is important is to find out the real patient's reason of the expressed will, taking into account the new circumstances as well. The patients' express of their will in healthcare process can be multidisciplinary. No doubt that the patient mostly expresses his or her will according to his or her treatment. (Kudeikina, Palkova : 2016) And the patient is the only one who can make the will of the treatment broader or narrow the will. And if the patient decides to broaden the will of the treatment in healthcare process, it means that he expresses his will according to the new conditions. In that case it can be considered as a new proposal for the treatment, new will of the patient.

The will of the patients in healthcare is connected to patient's ability to express the real wishes and emotions related to the treatment. From international point of view the individual's rights to freely express the will in healthcare process can be met also in the European Convention on Human Rights. According to the Article 3 of the European Convention on Human Rights no one shall be subjected to torture or to inhumane attitude or degrading. The Article 3 can be transformed and viewed from the person's perspective in healthcare cases or from the patient's perspective, because human rights are a multi-disciplinary field (Wolfgan Benedek: 2018).

The human rights of any person, the rights to health etc., are embedded both at international and national level. The stated rights are attributed also to patients. The rights and consequences of medical treatment in the case where patient did not express his $\backslash$ her will could, in some circumstances, be considered as degradation of positive rights. For instance, according to the decision of the European Court of Human Rights the treatment without the will of the person, in theory, breaches the Article 3.

At the same time the court said that in the case Herczegfalvy vs Australia, treatment hadn't reached necessary stage to show that medical treatment breached Article 3. (The European Court of Human Rights, Herczegfalvy vs Australia 1992). 
This was established by the Human Rights Court in a case called Herczegfalvy v Austria, where a man called Mr Herczegfalvy was given sedatives and other medical treatment without his consent in a psychiatric hospital. The court agreed that treatment without consent could, in theory, breach Article 3, but said that in this case Mr Herczegfalvy's treatment hadn't reached that stage. To show that medical treatment breached Article 3, it had to be shown that the harm met a minimum level of severity, and that the treatment wasn't medically necessary.

It should be noted, that even when the person's and patient's will and the expression of that will are protected by human rights principles, there are still plenty of problems. The will of the patient can be regarded as the core of the legal relationship between the patient and the medical practitioner / institution.

The institute of the will of the patient is quite complex. It involves many legal nuances. One of the criteria for the validity of the patient's will is the patient's ability to express his or her will without restrictions.

One of the elements that shows the problematics in patient's will expression institute is capacity of the patient. The capacity of the patient shows the real validity of the patient's will, in other word it is the patient's ability to express his or her will.

The autonomy of the patient to make personal medical decisions is one of the fundamental principles of medical ethics. (Christopher Libby:2019). However, there are situations when a patient is not able to express the real will or decision for themselves in treatment procedure.

And in such case, there is the problem, when patients can make decision that will not be in their best interest.

There are several forms of civil consent capacity, but the patient's capacity issue in the healthcare is important because of the direct affection of the person's right to decide what happens to one's own body. (Barton W. Palmer: 2016).

It should be noted, that for instance, after Law on the Rights of Patients came into the force in Latvia on $1^{\text {st }}$ on March 2010, the regulatory framework regarding the will of the patient became more specified. Nevertheless, there are still some problematic issues regarding to patient capacity (Law on the Rights of Patients: 2010). According to Paragraph 1 of Section 6 of the Law on the Rights medical treatment is permissible if a patient has given the informed consent thereto.

The patient has the right to ask questions and receive answers prior to giving the informed consent. It means that in Latvia the will of the patient is wide enough to accept or refuse the treatment if the patient is capable. But in case of incapable person there are some specific regulations that restrict person's rights to express the will in healthcare.

Next section states that the informed consent shall be drawn up in writing if it is requested by the patient or the attending physician. From this perspective the patient is restricted to freely disclose the will because of the obligation to drawn informed consent. If the patient will change the will during the treatment, new documentation will be needed and this may cause some legal problems.

To protect the interests of the patients as well as the medical practitioners, the Law provides to the patients, if the informed consent is given in writing, approve it by his or her signature and append this document to patients' medical documents. From the 
perspective of expression of the patient's will again there is a restriction in expression of free will of the patients, based on the necessity to approve it in writing.

Section 6 of the Latvian Law on the Rights of Patients also says that a patient has the right to refuse medical treatment prior to the commencement thereof, from any method used in the medical treatment, without declining from the medical treatment at large, or to refuse medical treatment during it. In such case the patients are free in their decision and the will of the patients is not restricted. Important is communication between medical practitioner and patients. (Palkova: 2018)

In the case of incapable patients there are specific and more difficult regulations. As European Court of Human rights was mentioned in cases where States impose legal incapacity on mentally ill individuals, the Court has articulated procedural requirements necessary to protect Article 8 of the European Convention on Human Rights. The Court has held that the deprivation of legal capacity undeniably constitutes a serious interference with the right to respect for a person's private life protected under this article. Besides, the court says that the capacity to act independently in almost all areas of his life is one of the important rights. Therefore, the expression of the will of the incapable patient is a crucial element in human rights context. Finally, the Court has held that States must provide adequate safeguards to ensure that mentally disabled individuals are able to participate in all process as well as in healthcare. (Guide on Article 8 of the European Convention on Human Rights:2019). For instance, according to the Section 356.1 of the Latvian Civil Code the court may not restrict the person in the case of personal non-property rights (for example, it may not prohibit marriage, wills or limit the person's legal capacity in matters concerning his or her health or medical treatment). (Latvian Civil Code: 1937). This means, for example, that a person may decide to undergo hospital treatment or not. The person cannot be treated in a hospital without their explicit informed consent. Exception is regulations provided in the Latvian Law on the Rights of Patients and Latvian Medical Treatment Law.

The capacity of the patient to make the decision in healthcare is related to the ability of the patient. This decision or will expressed by incapable patient must be truly understood by third parties. But the changes, for instance, in a patient's mental status can affect his or her capacity to make a particular medical decision and express their true will.

Section 7 of the Latvian Law on the Rights of Patients includes the information about the right of another person to agree to medical treatment or to refuse it. It says, that if a patient is unable to make a decision for himself or herself, the relatives, for instance the spouse of the patient, have the right to make that decision on medical treatment. But if such does not exist, an adult closest relative with capability to act in the following order: the children of the patient, the parents of the patient, the brother or sister of the patient, the grandparents of the patient or the grandchildren of the patient. (Latvian Law on the Rights of Patients: 2010.) The will of the incapable patient is restricted due to the lack of capacity. Nevertheless, to protect the best interests of the incapable person the spouse or closest relative of a patient or a person authorized by the patient, as well as the lawful representative of the patient, shall observe the wish previously expressed by the patient in relation to medical treatment. (Latvian Law on the Rights of Patients: 2010.).

Of course, there are some exceptions when the rights of the will expression of the incapable patient can be restricted almost absolutely. Section 7 of the Latvian Law on 
the Rights of Patients states that the decision on medical treatment, which would have the most favourable effect on the state of health of the patient, shall be taken by the doctors' council. In this situation some circumstances must be met. First one - a patient has not indicated a person who is entitled to consent to medical treatment or to refuse it on behalf of the patient. Second one - the patient has no spouse, closest relative or lawful representative. Third one - the patient has forbidden in writing the spouse or closest relative from making the decision on his or her behalf.

Besides, in cases where a delay may endanger the life of the patient and it is not possible to receive the consent of the patient himself or herself or the person representing the patient, the medical practitioner shall perform emergency measures within the scope of his or her competence - examination, medical treatment, including surgical or other type of invasive intervention. In such cases an examination and medical treatment plan shall be approved and a decision taken by a doctors' council, except in cases where first aid or emergency medical care has to be provided. (Latvian Law on the Rights of Patients: 2010.). In such specific cases the patient cannot express the real will during the healthcare process.

\section{Conclusion and Implications}

The effective control of the will of the party to the transaction currently exists outside the legal framework. It is subject only to the subjective appraisal of the party to the transaction (the other party or an official). In fact, the legal framework does not even oblige a party to ascertain the legal capacity of its counterparty. Only a sworn notary has such an obligation when drafting notarial deeds. (Notariate Law: 1993). Thus, only in narrowly defined cases is the will subject to a balanced assessment. It should be emphasized that the Latvian legislature has made the notarial order obligatory for a very limited number of transactions (e.g. inheritance agreement, marriage contract, divorce application, application for acceptance or dismissal of inheritance). There is a large segment of private transactions, including real estate mortgages and expropriations, which can be concluded in private procedure.

Medical practitioners do not rank patients at all and seek informed consent for treatment from anyone, regardless of their legal capacity. This approach follows from the Paragraph 1 of Section 6 of the Law On the Rights of Patients (2010). The question is, how conscious can a statement of will be and, accordingly, how much legal informed consent, if given by an incapacitated person?

In the case of private transactions, there is also no legal mechanism for dealing with cases where the partner is found to be incapable at the time of the transaction. There is no mandatory legislation prohibiting the transaction. This poses a threat to legal stability because even if the counterparty is incapacitated, the other party to the transaction may enter into a transaction. There is a conflict of laws - the legal framework states that transactions concluded by incapacitated persons are not valid, but there are no criteria for assessing legal capacity and the conclusion of a transaction is not prohibited.

When improving the legal framework, it would initially be mandatory to prohibit the conclusion of a transaction with an incapacitated person. This would preclude the possibility of an action for a declaration of invalidity in cases where it was concluded 
with knowledge of the party's incapacity. There must be a legal denial that a claim for a nullity of a transaction cannot be declared valid if the person concerned has himself concluded such a transaction on the knowledge that the counterparty is incapacitated. Thus, it is also necessary to establish an obligation for the party to verify the counterparty's capacity in private transactions. A capacity clause or a statement on mutual control over capacity should be included in the transaction deed.

Physicians should assess the patient's capacity when initiating patient's treatment and do not require informed consent from incapacitated patients. In such cases, the responsibilities of the medical practitioner should include an obligation to self-assess the usefulness of the treatment by informing the spouse or next of kin of the incapacitated patient. The informed consent of the patient should have been obtained after the restoration of legal capacity.

\section{References}

Herbert G.M. Hermanis. Patients' rights in the European Union Cross-border care as an example of the right to health care. European Journal of Public Health, 1997, 7/3 supplement 11-17.

Kudeikina I., Palkova K. "Issues of Legal Organization of the Patient-Health Care Professional Relationships" (co-author Kudeikina, I.). European Center for science education and research, Conference proceedings, ICSS VIII, European Journal of Multidisciplinary Studies, 2016, ISSN 2414-8385. https://dukonference.lv/files/proceedings_of_conf/978-9984-14-7796_58\%20konf\%20 kraj_B_Soc\%20zin.pdf. Indeksēts Google Scholar, Cross Ref. Accessed 12.12.2019.

Palkova K., "Medical Personnel's Legal Awareness as the Key of Principal Quality of Work with Minor Patients." 12th International scientific conference "Society. Integration. Education". Proceedings of the International Scientific Conference. Rezekne Academy of Technologies, 190-198, 2018. (http://journals.ru.lv/index.php/SIE/article/view/3165). Accessed 12.12.2019.

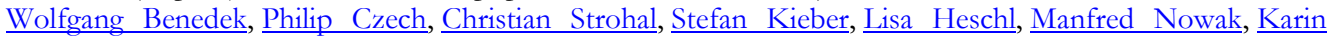
Lukas. European Yearbook on Human Rights, 2018, 478

Zapotoczna Z., Patient Engagement Technology in the light of patients' rights to information. Seventh European Conference on Health Law, Book of Abstract. European Association of Health Law, 2019, 40.

The European Court of Human Rights. CASE OF HERCZEGFALVY v. AUSTRIA. (Application no. 10533/83). JUDGMENT. STRASBOURG. $24 \quad$ September 1992. fhttps://hudoc.echr.coe.int/eng\#\{\%22itemid\%22:[\%22001-57781\%22]\}) Accessed 11.12.2019.

Barton W. Palmer, Alexandrea L. Harmell. Assessment of Healthcare Decision-making Capacity. Archives of Clinical Neuropsychology 31 (2016) 530-540. Oxford University press. 2016.

Law On the Rights of Patients. Latvia, 2010. https://likumi.lv/ta/en/id/203008-law-on-the-rights-ofpatients Accessed 14.12.2019.

Christopher Libby; Gary Gillette. Competency and Capacity.2019. https://www.ncbi.nlm.nih.gov/books/NBK532862/

European Court of Human rights. Guide on Article 8 of the European Convention on Human Rights: Right to respect for private and family life, home and correspondence. 2019. https://www.echr.coe.int/Documents/Guide Art 8 ENG.pdf Accessed 09.12.2019.

Mazure. $\quad$ L., Pacienta griba un tās civiltiesiskā aizsardzība. 2011. https://dspace.lu.lv/dspace/bitstream/handle/7/5100/20560-

Liga Mazure 2011.pdf?sequence $=1$ \&isAllowed $=\mathrm{y}$ Accessed 10.12.2019.

Griba. Latvian Oxford Livings Dictonaries. https://lv.oxforddictionaries.com/skaidrojums/GRIBA

Osipova, S. Tiesību sociolog̣ija kā juridiska zinātne un tās ǵenēze, Latvijas Universitātes raksti, Nr.703, Rīga, 2006. 
https://dspace.lu.lv/dspace/bitstream/handle/7/4515/Zinatniskie_raksti_703_sej_Juridiska_zina tne_2006_sn316612_OCR.pdf?sequence=1

Civil code.

http://www.vvc.gov.lv/export/sites/default/docs/LRTA/Likumi/The_Civil_Law.doc Accessed 12.12.2019.

Latvijas Republikas Civillikuma komentäri. Ceturtā dala. Saistïbu tiesïbas. Autoru kolektīus prof. K.Torgäna vispärīgä rinätniskā redakcijā. - Rigga: Mans İpašums, 2000, 24.lpp.).

Latvijas Republikas Augstākās tiesas Civillietu departamenta 2017.gada 26.maija spriedums lietā Nr. C30614710; SKC-166/2017. http: $/$ www.google.lv/url?sa $=$ t\&rct=j\&q $=\&$ esrc $=$ s\&source $=$ web\&cd $=1 \& v e d=2 a h U K E w j h h O D$ UiqHmAhXB4aYKHReACq0QFjAAegQIBBAC\&url=http\%3A\%2F\%2Fwww.at.gov.lv\%2Fdow nloadlawfile\%2F5175\&usg=AOvVaw38qj8aMxcjqHMtgUnvhiji

Kudeikina I., Kopīpašuma institūta problemātika darījumos ar nekustamo īpašumu. Rīga, 2015. https://www.rsu.lv/sites/default/files/dissertations/Kudeikina_disertacija_DRUKAI.pdf

Administratīiās rajona tiesas 2011.gada 12.septembra spriedums lietā Nr.A420626810, A2156-11/6. http://www.tiesas.lv/files/AL/2011/09_2011/12_09_2011/AL_1209_raj_A-02156-11_6.pdf.

Notariāta likums. Latvia, 1993. https://likumi.lv/ta/id/59982-notariata-likums 